\title{
ACARICIDAL ACTIVITY OF INERT POWDERS AGAINST THE POULTRY RED MITE Dermanyssus gallinae (DE GEER, 1778) (Mesostigmata: Dermanyssidae)
}

\author{
Ação acaricida de pós inertes contra o ácaro-vermelho Dermanyssus gallinae (De \\ Deer, 1778) (Mesostigmata: Dermanyssidae)
}

*Luis Francisco Angeli Alves', Daian Guilherme Pinto Oliveira², Cristiane Regina Kasburg1, Margaret Seghetto Nardelli ${ }^{1}$

${ }^{1}$ Universidade Estadual do Oeste do Paraná - Unioeste, ${ }^{2}$ UTFPr, Campus Santa Helena

*Corresponding author: luis.alves@unioeste.br

\begin{abstract}
Dermanyssus gallinae is one of the most important ectoparasite of laying hens. The intensive use of chemicals has led to the selection of resistant mite populations. The difficulty in controlling the mites has promoted the search for alternative products. Thereby, the aim of this study was to assess in laboratory the acaricidal activity of inert mineral powders against $D$. gallinae, in dust and water suspensions (5 and 10\%) treatments. The products were tested against eggs, nymphs and adults of the mite. There were differences in the activity of tested products. Some products based on diatomaceous earth, kaolin and talc, applied in powder form on adults of the mite were more efficient and selected for subsequent tests. In liquid suspension bioassay it was observed no ovicidal activity of any of the tested products. However, the products were efficient on the nymphs with no difference between both products and concentrations. The activity of diatomaceous earth and Kaolin 2120 in 5 and 10\% water suspension on adults was significatively higher than other treatments against adults. There was no difference between the treatments in residual activity. The morphological characterization and identification of diatom frustules present in the product PosturaSec ${ }^{\circledR}$ indicated prevalence of the genus Brachysira Kützing, density of $5.7 \times 10^{7}$ valves $/ \mathrm{g}, 200 \mu \mathrm{m}$ size particles and $86.2 \%$ of silicon.
\end{abstract}

Keywords: animal production, alternative control, ectoparasite.

RESUMO: Dermanyssus gallinae é um ácaros de maior importância na postura comercial. O uso intensivo de produtos químicos tem levado a seleção de populações do ácaro resistentes. A dificuldade em controla-los faz com que se busquem produtos alternativos. Assim, o presente trabalho teve por objetivo avaliar, em laboratório, a ação acaricida de pós minerais inertes contra $D$. gallinae, em aplicações em pó e em suspensão aquosa (5 e 10\%). Os produtos foram testados contra ovos, ninfas e adultos do ácaro. Houve diferença na atividade dos produtos testados. Alguns deles, à base de terra de diatomáceas, caulim e talco, aplicados em pó sobre os ácaros adultos e selecionados para testes seguintes. Nos bioensaios com suspensão em água, não foi observada ação ovicida de nenhum dos produtos testados. Contudo, todos os produtos foram ativos contra ninfas, não havendo diferença significativa entre eles. A atividade da terra de diatomáceas e do caulim 2120 nas concentrações de 5 e 10\% em água foi significativamente maior que os outros tratamentos. Não houve diferença entre os tratamentos no teste residual. $\mathrm{Na}$ caracterização morfológica e identificação das frústulas de diatomáceas presentes no produto à base desse mineral, verificou-se prevalência do gênero Brachysira Kützing, com densidade foi de 5,7 $\times 10^{7}$ valvas $/ g$, partículas 
com $200 \mu \mathrm{m}$ e $86,2 \%$ de sílica.

Palavras-chave: produção animal, controle alternativo, ectoparasita. 


\section{INTRODUCTION}

The poultry red mite Dermanyssus gallinae (De Geer, 1778) (Mesostigmata: Dermanyssidae) is a cosmopolitan hematophagous ectoparasite of laying hens. It is frequently found in aviaries throughout the year (Pritchard et al., 2015). D. gallinae leads to anaemia, behavioural changes, skin irritation, feather loss, excessive pecking, and dermatitis in hens. Egg production is also affected, both in quantity and quality. Premature bird deaths have also been observed. In addition, it can constitute a vector of pathogens of veterinary importance, including Salmonella enterica serotype Gallinarum and Salmonella enterica serotype Enteritidis. There are also reports of discomfort and dermatitis in workers of highly infested aviaries (Rosen et al., 2002; Moro et al., 2009; Pereira, 2009; Cunha, 2013; Pritchard, 2015).

Chemical acaricides are used with relative efficacy in mite control. However, indiscriminate use has made populations of mites resistant to pyrethroid and organophosphorous pesticides, as well as to other compounds (Nordenfors et al., 2001; Abbas et al., 2014), and promoted the presence of residues of these products in eggs (Romão, 2007; Ciscato, 2008; Liebisch et al., 2011; Sparagano et al., 2014; Pritchard et al., 2015). In addition, the production of poultry outside cages has been encouraged, either by the market or by law (Murillo and Mullens, 2016), which, together with restrictions on the use of chemicals in organic production systems, and increased demand for eggs, has reinforced the need for safe and more effective control of poultry mites.

Inert powders are present in the poultry industry, especially hydrated lime and diatomaceous earth. They are used as sanitizers for poultry houses, reducing ammonia production and proliferation of lesser mealworms
Alphitobius diaperinus Panzer, 1797 (Coleoptera: Tenebrionidae) (Watson et al., 2003; Oliveira et al., 2017). Also, inert powder-based products have been marketed in Europe for over 40 years (Ebeling, 1971; Pritchard et al., 2015) in liquid and powder formulations, interfering with reproduction and survival of mites (Kilpinen and Steenberg, 2009; Maurer et al., 2009; Shulz et al., 2014; Alves et al., 2017).

The acaricidal activity of powders occurs physically by abrasion of the cuticle after first contact, which removes the lipid layer and causes excessive water loss and desiccation (Ebeling, 1971; Kilpinen and Steenberg, 2009; Maurer et al., 2009; Schulz et al., 2014, Amalin et al., 2015). It should be noted that powder application leads to loss of material by dispersing in the environment with formation of dust clouds. For this reason, some products are available in liquid formulations, because they are more advantageous. These products minimise the problems abovementioned, especially pulmonary silicosis (Santesson, 2013; Sparagano et al., 2014). With respect to $D$. gallinae, Maurer and Perler (2006) and Schulz et al. (2014) observed that different silicabased dry and liquid products and preparations exhibited variations in control efficiency. These authors highlighted the acaricidal activity of liquid preparations.

Given that these products are of mineral origin, there is great variation in the physicochemical composition and the morphology of the particles. The effects of these variations on the insecticidal activity have been proven (Korunic, 1997, 1998, 2013). The goals of the present study were to assess the acaricidal activity of inert powders of Brazilian origin used in dry and liquid applications against different development stages of poultry red mite D. gallinae, and perform a morphological 
characterisation of silica-based products.

\section{MATERIALS AND METHODS}

Mites

The mites (eggs, nymphs, and adults) were collected in a commercial poultry house. In the laboratory, the eggs were transferred to Petri dishes and the nymphs and fed adult females were placed in glass tubes sealed with voile fabric and kept for 1 day at climate room $\left(25 \pm 1^{\circ} \mathrm{C}, 14\right.$-h photophase, $70 \pm 5 \%$ $\mathrm{RH}$ ) to be used in bioassays.

\section{Products}

Twelve products of mineral origin were tested (Table 1). The product PosturaSec ${ }^{\circledR}$, based on micronized diatomaceous earth - Vet Science Bio Solutions Ltd. (www.vetscience.com.br), was used as a comparison standard. The following controls were used: a group treated with commercial corn starch (in powder or in water suspension) and other group untreated (total control group).

The study was divided into two phases. In the first one, all the products were assessed through dry applications in $D$. gallinae adults. The products that caused a minimum mortality of $90 \%$ were selected. In the second phase, these products were suspended in distilled water at 5 and $10 \%$ and used against eggs, immature and adult mites.

Acaricidal activity of products against Dermanyssus gallinae

\section{Dry products}

Fifteen fed adult female were transferred into glass tube $(\varnothing 2 \times 7 \mathrm{~cm})$ sealed with Parafilm $^{\circledR}$ membrane containing sterile filter paper $(7 \times 7 \mathrm{~cm})$ previously treated with $14 \mathrm{mg}\left(2.8 \mathrm{~g} / \mathrm{m}^{2}\right)$ of each product on the surface. The tubes were kept at room $\left(25 \pm 1^{\circ} \mathrm{C}\right.$, $70 \pm 5 \% \mathrm{RH}, 14 \mathrm{~h}$ photophase). In all treatments and controls, seven tubes were used as replicate.
Table 1 - Products assessed in vitro against red poultry mite Dermanyssus gallinae: composition and manufacturer.

\begin{tabular}{lll}
\hline \multicolumn{1}{c}{ Product } & \multicolumn{1}{c}{ Composition } & \multicolumn{1}{c}{ Manufacturer } \\
\hline A-Bind $^{1}$ & Thermo activated natural bentonite & Vet Science \\
Kaolin $^{2}$ & Hydrated aluminium silicates & Vet Science \\
PosturaSec $^{\circledast 3}$ & Diatomaceous earth (Diatomite) & Vet Science \\
${\text { Vermiculite DM } 430^{2}}^{\text {Vermiculite DM } 440^{2}}$ & Vermiculite & Gold Star Brasil \\
\hline Calcium carbonate OB $1000^{2}$ & Vermiculite & Gold Star Brasil \\
Calcium carbonate OB $1130^{2}$ & Calcium carbonate & Minérios Ouro Branco \\
Calcium carbonate OB $1170^{2}$ & Calcium carbonate & Minérios Ouro Branco \\
Kaolin OB 2120 & Hydrated aluminium silicates & Minérios Ouro Branco \\
Kaolin OB $2130^{2}$ & Hydrated aluminium Ouro Branco \\
Talc OB $3130^{2}$ & Magnesium silicates & Minérios Ouro Branco \\
Talc OB $3510^{2}$ & Magnesium silicate & Minérios Ouro Branco \\
\hline NOte. & Minérios Ouro Branco \\
\hline
\end{tabular}

Note. ${ }^{1}$ product indicated as aflatoxin adsorbent for use in aviaries; ${ }^{2}$ there is no indication for field use; ${ }^{3}$ recommended for faecal drying and environment sanitation in commercial poultry houses.

The mites were daily observed by using a stereomicroscope for five days. Mites were considered dead if no movement was visible after a with a paint brush. The experiment was repeated twice.

\section{Products in aqueous suspension} Direct activity

Ovicidal activity. Mite eggs obtained in the laboratory (24 hours after oviposition) were distributed in Petri dishes and sprayed with $2 \mathrm{~mL}$ of the aqueous suspensions (5 and $10 \%$ in distilled water) using a Potter tower $\left(0.70 \mathrm{kgf} / \mathrm{cm}^{2}\right)$. After drying under ambient conditions, Petri dishes were sealed with Parafilm ${ }^{\circledR}$ membrane and kept at the same condition before. Five replicates and control were conducted. The assessments were performed daily, for three days, counting the number of hatched, whether dead or alive, by using a stereomicroscope.

Activity against nymphs and adult D. gallinae. The procedure described above was repeated but applying $1 \mathrm{~mL}$ of the suspensions of each product directly to non-sexed nymphs in Petri dishes. To avoid escaping mites, petroleum jelly was applied as a barrier to the edges of the dishes. After drying, the mites were transferred with a paint brush to glass tubes sealed with voile 
fabric and kept under the same condition as the eggs.

The same procedures were performed in the test with adults; but 2 $\mathrm{mL}$ of suspensions were applied on the mites.

\section{Residual activity}

All the same procedure of the tests with the dry products was repeated with suspension of each product, except that the filter paper $(7 \times 7 \mathrm{~cm})$ was immersed for 10 seconds in the suspensions of each product with concentrations of 5 and $10 \%$.

Morphological characterisation and identification of diatom species in silicabased products

For genus identification and size determination of diatom frustules (whole or fragment), a sample of $1 \mathrm{~g}$ of product was suspended in $50 \mathrm{~mL}$ of distilled water, and $0.1 \mathrm{~mL}$ aliquots were used in permanent slides. This permanent slides were made using Naphrax $\AA$ as mountant (refractive index 1.74; Brunel Microscopes Ltd.). Photomicrographs were obtained in a microscope coupled digital camera. Diatom frustules were measured (greater and smaller length) with Axio Vision 4.8 software (Carl Zeiss Vision\AxioVision 4\AxioVs40). The identification of genera was based on Krammer and Lange-Bertalot (1991), Round et al. (2005), Metzeltin et al. (2005), Metzeltin and Lange-Bertalot (2007) and Costa et al. (2017).

Relative abundance and density was obtained by counting valves in transects at $1000 \times$ magnification. The minimum valve count threshold was 400 in total, and minimum counting efficiency was $90 \%$ as Pappas and Stoermer (1996): Efficiency $=1$ - (number of species/total number of valves).

Density was determined using the sedimentation method (Battarbee, 1986). The results of density of diatomaceous earths were expressed in individuals/g and obtained using the formula below:

$$
\mathrm{N}=\left(\mathrm{n} \times \frac{\mathrm{AL}}{(\mathrm{Nc} \times \mathrm{Ac})} \times \frac{\mathrm{V}}{\mathrm{V}}\right) / \mathrm{M}
$$

where: $\mathrm{N}=$ no valves/g dry weight; $\mathrm{n}=$ number of counted valves; $\mathrm{AL}=$ cover slip area; $\mathrm{Nc}=$ number of fields counted; Ac $=$ field area $\left(\mathrm{mm}^{2}\right) ; \mathrm{V}=$ volume of the initial sample; $\mathrm{v}=$ volume of the subsample $(\mathrm{mL}) ; \quad M=$ mass of the initial sample (g).

\section{Statistical Analysis}

The experiments were performed according to a completely randomised design. Mortality values were corrected using Schnider-Orelli formula (Püntener, 1981), and subsequently analysed for homogeneity using the Cochran test. For the parametric data, the statistical analysis to detect significant differences between treatments (comparison of the activity of the products and concentrations was conducted with oneway ANOVA and ANOVA Factorial with Tukey HSD test $(p \leq 0.05))$. For the nonparametric data, Kruskal-Wallis test ( $p$ $\leq 0.05$ ) using STATISTICA 7.1 (StatSoft Inc., USA, 2005).

\section{RESULTS AND DISCUSSION}

Acaricidal activity of the products against Dermanyssus gallinae

Dry products

All products showed activity against adult mites, ranging from 39 to $100 \%$ of mortality. The products Kaolin 2120, Kaolin 2130, PosturaSec ${ }^{\circledR}$, and Talc 3130 were the only ones to cause mortality above $95 \%$. So, they were selected for the next step (Table 2).

Previous studies proved the susceptibility of $D$. gallinae to some kind of silica-based and others mineral powders, with a great variation in the mortality (Kilpinen and Steenberg, 2009; Maurer et al., 2009). In this sense, it was observed in a comparison of acaricidal 
activity of 12 silica-based products that morphological characteristics of the particles were determinant for the greater activity of some products to the red mite, reinforcing the physical basis of the acaricidal activity of silica (Schutz et al., 2014).

As observed for diatomaceous earth, hygroscopicity has also been showed by other minerals and, in this sense, kaolins possess adsorptive and abrasive activity. They are largely used as vehicles for insecticides and, in addition, some of them have insecticidal activity according to their granulometric ranges (Glenn and Puterka, 2005; Amalin et al., 2015; Sarwar, 2016).

Even though acaricidal activity of Talc $3130(98.1 \%)$ and Talc 3510 (39\% mortality), in others study (Schulz et al. 2014; Kilpinen and Steenberg, 2009), talc and kaolin were considered to be less active against mites. It is generally accepted that besides minerals, other molecules may be present as adjuvants in the formulations, which have acaricidal activity that may affect the mites. Similarly, it is known that acaricidal activity is influenced by the origin, morphological characteristics, chemical composition of the mineral particles, surface chemistry in contact which can explain the activity of some talc and kaolin tested in this study (Japp, 2008; Schulz et al., 2014).

\section{Products in aqueous suspension \\ Direct activity}

Ovicidal activity. None of the tested products exhibited ovicidal activity against $D$. gallinae. Hatching values ranged from 84 to $90 \%$. These corroborate some of the results of the study conducted by Schulz et al. (2014) with powdered and liquid minerals used against eggs of $D$. gallinae, mainly which based on natural silica, with $90 \%$ of hatching. In addition, as in the present study, it was observed that there was mortality in newly hatched larvae (76 to $91 \%$ without significative difference) when they came in contact with the applied products (Table 2).

Activity against nymphs and adult D. gallinae. Mortality obtained with nymphs was higher than with the adults. The products Kaolin 2130 and PosturaSec ${ }^{\circledR}$, both at $5 \%$ concentration, stood out causing nymphs mortality of 95.7 and $98.9 \%$, respectively. There was no significant difference between the products at $10 \%$ concentrations (mortality ranging from 89 to $100 \%$ ). Regarding adults, the values obtained with a $1 \%$ concentration were significatively lower than obtained for the others concentrations. Besides, only PosturaSec ${ }^{\circledR}$ was different from control (49.5\% mortality). The mortality obtained at 5 and $10 \%$ concentration was not different from each other, ranging from $67 \%$ (Kaolin 2120) to $100 \%$ (PosturaSec $^{\circledR}$ ) (Table 2).

In the most treatments, for both nymphs and adults, increasing the dose results in higher mortality values. This fact was attributed to the greater coverage of the mites, and the abrasive and lipophilic character of the products, mainly PosturaSec ${ }^{\circledR}$, which is based on silica (Harrington et al., 2011). Even with the lowest concentration, mortality achieved by PosturaSec ${ }^{\circledR}$ can be attributed to the porosity of the diatom frustules that produce high hygroscopicity. This product is able to absorb water up to four times its weight and, thus, cause the death of the mites by dehydration (Horn-Veiga and Son, 1980).

As there was no significant difference between them, the concentration of $5 \%$ can be recommended for the control of the mites, representing efficiency at low cost to the producer. Diatomaceous earth is highly absorbent and abrasive due to the amount of silica $\left(95 \%\right.$ silica $\left[\mathrm{SiO}_{2}\right]$, alumina (2 to $4 \%$ ), and hematite (0.5 to $2 \%$ ) (Khraisheh et al., 2004; Wu et al., 2005). Its mode of action is 
characterised by physical control and does not depend on metabolic pathways. This way, mites can hardly develop resistance. However, is it possible they may develop behavioural mechanisms in order to avoid contact with these powders (Ebeling, 1971; Chauve, 1998; Maurer et al., 2009). For this reason, it can be inferred that, in addition to reducing the amount of product applied (less waste), the liquid form does not harm the health of the animals and the individuals, and allows greater coverage of the treated surface.

Table 2 - Mortality of nymphs and adult of Dermanyssus gallinae after spraying of inert powder suspensions at different concentrations.

\begin{tabular}{|c|c|c|}
\hline Treatment & \multicolumn{2}{|c|}{ Concentration } \\
\hline \multicolumn{3}{|c|}{ Immature } \\
\hline \multicolumn{3}{|l|}{ C̄ontrol } \\
\hline Starch & $9.4 \pm 5.0 \mathrm{Da}$ & $6.6 \pm 9.1 \mathrm{Ba}$ \\
\hline Postura Sec ${ }^{\circledR}$ & $98.9 \pm 2.8 \mathrm{Aa}^{*}$ & $98.9 \pm 2.8 \mathrm{Aa}^{*}$ \\
\hline Kaolin 2120 & $54.8 \pm 27.8 \mathrm{Cb}^{*}$ & $95.7 \pm 8.5 \mathrm{Aa}^{*}$ \\
\hline Kaolin 2130 & $95.7 \pm 5.9 \mathrm{Ba}^{*}$ & $100.0 \pm 0.0 \mathrm{Aa}^{*}$ \\
\hline Talc 3130 & $58.1 \pm 20.8 \mathrm{Cb}^{*}$ & $89.2 \pm 15.0 \mathrm{Aa}^{*}$ \\
\hline--- & Adult & \\
\hline & $\overline{0} . \overline{0} \pm 0 . \overline{\mathrm{Ca}}$ & $0 . \overline{0 \pm 0.0} \overline{\mathrm{C}} \overline{\mathrm{a}}$ \\
\hline Starch & $5.9 \pm 8.7 \mathrm{Ca}$ & $0.7 \pm 1.1 \mathrm{Cb}$ \\
\hline PosturaSec ${ }^{\circledR}$ & $98.8 \pm 3.1 \mathrm{Aa}^{*}$ & $100.0 \pm 0.0 \mathrm{Aa}^{*}$ \\
\hline Kaolin 2120 & $67.4 \pm 11.5 \mathrm{Ba}^{*}$ & $72.1 \pm 6.2 \mathrm{ABa}^{*}$ \\
\hline Kaolin 2130 & $77.1 \pm 25.2 \mathrm{ABa}^{*}$ & $73.3 \pm 18.2 \mathrm{ABa}^{*}$ \\
\hline Talc 3130 & $81.4 \pm 16.8 \mathrm{ABa}^{*}$ & $84.9 \pm 20.7 \mathrm{Ba}^{*}$ \\
\hline
\end{tabular}

Means $( \pm S E)$ followed by a lowercase letter in the row for each life stage of development and upper case letter in the column did not differ from each other according to the Kruskal-Wallis test; *Differed significantly from the respective control according to the Dunnet's test $(p<0.05)$.

In addition, it was observed that liquid formulations of diatomaceous earth had a higher residual effect in comparison to powder applications, causing above $90 \%$ mortality (Maurer and Perler 2006; Maurer et al., 2009). Recently, Schulz et al. (2014) demonstrated that liquid formulations were more effective against $D$. gallinae, exhibiting lower mean lethal time in comparison to powder applications.
Also, the authors highlighted the fact that instantaneous death of mites occurred by drowning in the droplets applied onto them and an additional acaricidal effect by the silica present in the product.

The activity of diatomaceous earth depends on a great number of factors which include environmental conditions (such as air humidity), particle size and shape, diatomaceous origin, type and purity of the formulation, as well as diatomaceous pores that may be related to a higher adsorptive capacity of lipids and water (Korunic, 2013, 2016). In this sense, significant differences in mortality of Alphitobius diaperinus were observed when submitted to diatomaceous earth from four regions of Argentina (Japp, 2008).

Based on these characteristics that may influence the insecticidal activity of diatomaceous earths, studies to their characterisation are important in order to know the morphological profile of the components.

\section{Residual activity}

All products selected sprayed on the filter papers exhibited high acaricidal activity mainly PosturaSec ${ }^{\circledR}$ that was the most effective, leading to $100 \%$ mortality in both concentration. Although there was not statistical difference between them (85 to $100 \%$ mortality). This confirms that mites were able to picks up enough product to be killed. This also suggests the need of thoroughly treatment of all surfaces in a shed and also the need for reapplication where the treated surfaces become covered by debris and dust (Kilpinen and Steenberg, 2009).

Morphological characterisation and identification of diatom species in the product PosturaSec ${ }^{\circledR}$

There was predominance of the classes Bacillariophyceae (six genera) and Fragilariophyceae (one genus). Brachysira Kützing stood out with an 
occurrence of $56.8 \%$ (Table 3, Figure 1). The density was $5.7 \times 10^{7}$ valves $/ g$ and the maximum size was $200 \mu \mathrm{m}$ for the frustules, and $3 \mu \mathrm{m}$ for non-identifiable fragments. Still, according to the manufacturer, PosturaSec ${ }^{\circledR}$ has $86.2 \%$ of silicon.

Such results are similar to those obtained by Alves et al. (2017), who assessed a similar product to control the lesser mealworm. The authors found eight genera of the class Bacillariophyceae and one of the class Fragilariophyceae. As observed in the present study, they also found predominance of the genus Brachysira Kützing. The size of the diatom frustules was also similar, varying from 3 to 120 $\mu \mathrm{m}$.

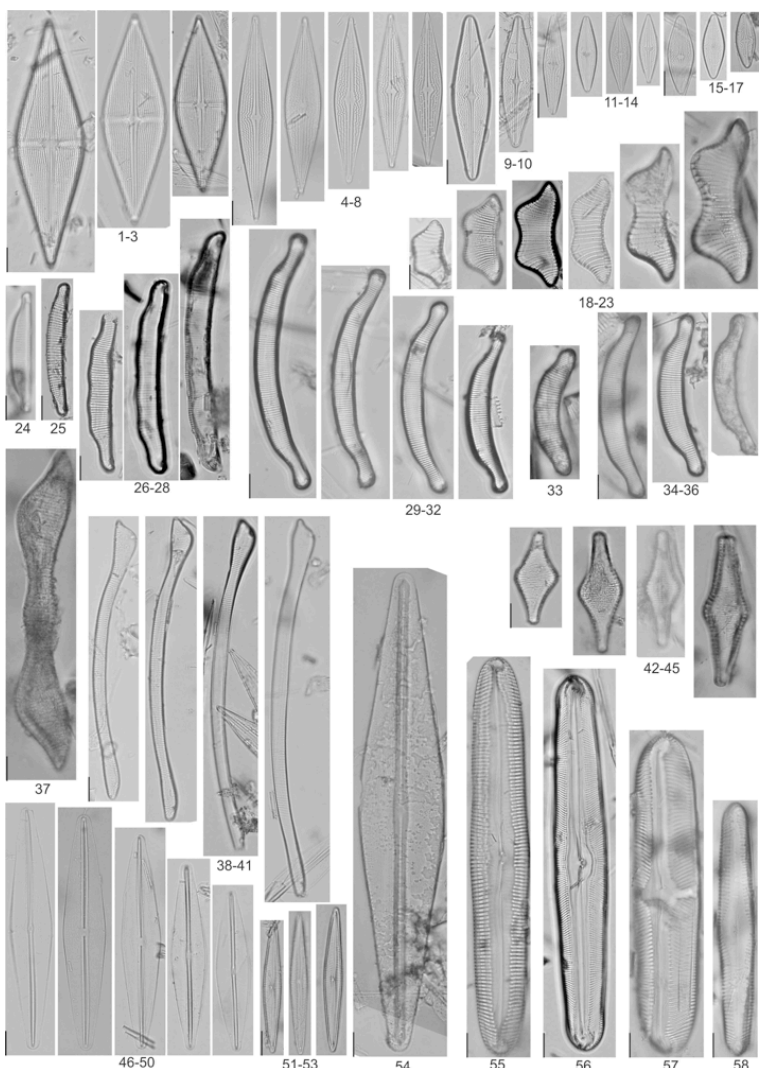

Figures 1-58 - Diatom ${ }^{54}$ genera found in the diatomite sample: 1-17 - Brachysira Kützing; 1837 - Eunotia Ehrenberg; 38-41 - Actinella Lewis; 42-45 - Fragilariforma Williams and Round; 4650 - Frustulia Agardh; 51-53 - Encyonopsis Krammer; 54 - Frustulia Agardh; and 55-58 Pinnularia Ehrenberg; Scale $=10 \mu \mathrm{m}$.

However, Japp (2008) analysed samples of diatomaceous earth from different origins in Argentina and found greater diversity of algae of the genus Fragilaria, present in all samples analysed. The genus Aulacoseira was found in only one sample, proving the existing relationship between the origin of the mineral and its morphological characteristics.

Morphological characterisation is important to explain the activity of inert powders, given that it is directly related to the physical properties of the particles, such as size, pore diameter, and moisture content (Schulz et al., 2014). With respect to diatomaceous earth, it is also necessary to assess silicon contents, given that the direct relationship of the activity with the amount of silicon dioxide, and the inverse relationship with particle size and uniformity have been proven (ideally less than $10 \mu \mathrm{m}$ ) (Korunic, 2013).

Table 3 - Identification and determination of diatom frustules present in the product Postura $\mathrm{Sec}^{\circledR}$.

\begin{tabular}{lcc}
\hline \multicolumn{1}{c}{ Genus/Family } & $\begin{array}{c}\text { Number of } \\
\text { Valves }\end{array}$ & $\%$ \\
\hline Brachysira Kützing / Bacillariophyceae & 300 & 56.8 \\
Frustulia Agardh / Bacillariophyceae & 156 & 29.5 \\
Eunotia Ehrenberg / Bacillariophyceae & 31 & 6.0 \\
Encyonopsis Krammer / Bacillariophyceae & 20 & 3.7 \\
Pinnularia Ehrenberg / Bacillariophyceae & 14 & 2.6 \\
Actinella Lewis / Bacillariophyceae & 5 & 1.0 \\
Fragilariforma Williams and Round / Fragilariophyceae & 2 & 0.4 \\
\hline
\end{tabular}

Specifically for $D$. gallinae, It was found that the smaller the size of the diatomaceous earth particles, the greater the acaricidal activity. This fact is due to the ease of adhesion, abrasion, and desiccation (Schulz et al., 2014). Other effects of diatomaceous earth include the asphyxia caused by the closure of the spiracles due to the presence of small particles (Korunic, 2016).

\section{CONCLUSION}

Based on our results, it can be affirmed that PosturaSec $^{\circledR}$ exhibits 
desirable characteristics and can be used against $D$. gallinae, both in the dry powder and liquid formulations. Tests performed in poultry houses are recommended in order to confirm the acaricidal activity of the product and its capacity to reduce mite populations.

Regarding the other products tested in the present study (Kaolin 2120, Kaolin 2130, and Talc 3130), a more detailed analysis is required to assess their composition, particle size, and mode of action. Also, field tests should be performed to determine the efficiency of the products.

\section{ACKNOWLEDGMENTS}

To CNPq, CAPES and Vetscience Biosolutions for financial support to this research.

\section{REFERENCES}

ABBAS, R. Z.; COLWELL, D. D.; IQBAL, $Z$.; et al. Acaricidal drug resistance in poultry red mite (Dermanyssus gallinae) and approaches to its management. World's Poultry Science Journal, v.70, n.1, p.113-124, 2014.

ALVES, L. F. A.; MARTINS, C. C.; NARDELLI, M. S.; et al. [2017]. In vitro assay and morphological characterization of a new product based on diatomaceous earth for lesser mealworm control in poultry houses. Arquivos do Instituto Biológico, v.84, n. e0782015, 2017. Available from $<$ http://www.scielo.br/scielo.php?script=s ci_arttext\&pid=S1808-

$1 \overline{6} 572017000100210 \&$ Ing=en\&nrm=iso $>$ . access on 28 Oct. 2018.

AMALIN, D. M.; AVERION, L.; BIHIS, D.; et al. Effectiveness of kaolin clay particle film in managing Helopeltis collaris (Hemiptera: Miridae), a major pest of cacao in the Philippines. Florida
Entomologist, v.98 n.1, p.354-355, 2015.

BATTARBEE, R. W. Diatoms analysis. In: BERGLUND, B. E. (ed). Handbook of Holocene Palaeoecology and Palaeohydrology. 1ed. Chichester: John Wiley \& Sons, 1986, p.527-570.

CHAUVE, C. The poultry red mite Dermanyssus gallinae (De Geer, 1778): current situation and future for control. Veterinary Parasitology, v.79, n.3, p.239-245, 1998.

CISCATO, C. H. P. Resíduos de praguicidas em amostras de ovo comercializadas na cidade de São Paulo. 2008. São Paulo, 105f. Thesis (Doutorado em Patologia Experimental e Comparada) - Faculdade de Medicina Veterinária e Zootecnia, Universidade de São Paulo.

COSTA, L. F.; WETZEL, C. E.; LANGEBERTALOT, $H$. et al. Taxonomy and ecology of Eunotia species (Bacillariophyta) in southeastern Brazilian reservoirs. Bibliotheca Diatomologica, v.64, p.1-302, 2017.

CUNHA, L. M. Aspectos epidemiológicos relacionados à ocorrência de ácaros hematófagos em granjas comerciais de postura no estado de Minas Gerais e avaliação de armadilhas para captura de Dermanyssus gallinae (Acari: Dermanyssidae) (De Geer, 1778). 2013. Belo Horizonte (MG), 96f. Thesis (Doutorado em Ciência Animal) Faculdade de Veterinária, Universidade Federal de Minas Gerais.

EBELING, W. Sorptive dusts for pest control. Annual Review of Entomology, v.16, n.1, p.123-158, 1971.

GLENN, D. M.; PUTERKA, G. Particle films: a new technology for agriculture. In: JANICK, J. (ed.). Horticultural Review. 1ed. New Jersey: John Wiley \& Sons, 2005, cap.1, p.1-44. 
HARRINGTON, D. W. J.; GEORGE, D. R.; GUY, J. H. et al. Opportunities for integrated pest management to control the poultry red mite, Dermanyssus gallinae. World's Poultry Science Journal, v.67, n.1, p.83-94, 2011.

HORN-FILHO, F. X.; VEIGA, M. M. Beneficiamento do diatomito de canavieira do estado do Ceará. Brasilia: Departamento Nacional de Produção Mineral (DNPM - Tecnologia mineral, 8, Seção de Beneficiamento, 6), 1980, 21p.

JAPP, A. K. Influência do Alphitobius diaperinus (Panzer, 1797) (Coleoptera, Tenebrionidae) no desempenho zootécnico de frangos de corte e avaliação da terra diatomácea como estratégia para o seu controle. 2008. Curitiba (PR), 51f. Dissertation (Mestrado em Ciências Veterinárias) - Universidade Federal do Paraná.

KRAMMER, K.; LANGE-BERTALOT, $\mathrm{H}$. Bacillariophyceae: Centrales, Fragilariaceae, Eunotiaceae. In: ETTL, H.; GERLOFF, J.; HEYNIG, $H$. et al. Sübwasserflora von Mitteleuropa. 2.ed. Stuttgart: G. Fischer, 1991. p.1576.

KHRAISHEH, M. A; AL-DEGS, Y. S.; MCMINN, W. Remediation of wastewater containing heavy metals using raw and modified diatomite. Chemical Engineering Journal, v.99, n.2, p.177-184, 2004.

KILPINEN, O.; STEENBERG, T. Inert dusts and their effects on the poultry red mite (Dermanyssus gallinae). Experimental Applied Acarology, v.48, n.1-2, p.51-62, 2009.

KORUNIĆ, Z. Rapid assessment of the insecticidal value of diatomaceous earths without conducting bioassays. Journal of Stored Products Research, v.33, n.3, p.219-229, 1997.
KORUNIĆ, Z. Review Diatomaceous earths, a group of natural insecticides. Journal of Stored Products Research, v.34, n.2-3, p.87-97, 1998.

KORUNIĆ, Z. Diatomaceous Earths Natural Insecticides. Journal Pesticides and Phytomedicine, v.28, n.2, p.77-95, 2013.

KORUNIĆ, Z.; ROZMAN, V.; LIŠKA, A.; et al. A review of natural insecticides based on diatomaceous earths. Poljoprivreda, v.22, n.1, p.10-18, 2016.

LIEBISCH, G.; HACK, R.; SMID, G. Efficacy of spinosad against the poultry red mite, Dermanyssus gallinae (Mesostigmata: Dermanyssidae), in laboratory and field trials. Zoosymposia, v.6, n.1, p. 282-287, 2011;

MAURER, V.; PERLER, E. Silicas for control of the poultry red mite Dermanyssus gallinae. In: JOINT ORGANIC CONGRESS, 2006, Odense. Proceedings at Joint Organic Congress. Odense, 2006. p. 30-31

MAURER, V.; PERLER, E.; HECKENDORN, F. In vitro efficacies of oils, silicas and plant preparations against the poultry red mite Dermanyssus gallinae. Experimental Applied Acarology, v.48, n.1-2, p. 3141, 2009.

METZELTIN, D.; LANGE-BERTALOT, H.; GARCÍA-RODRIGUES, F. (Eds.). Diatoms of Uruguay. Iconographia Diatomologica. Germany: Koeltz Scientific Books, 2005. 736p.

METZELTIN, D.; LANGE-BERTALOT, H. (Eds.). Tropical diatoms of South America II. Iconographia Diatomologica. Germany: Koeltz Scientific Books, 2007. 320p.

MORO, C. V.; LUNA, C. J. D.; TOD, A. et al. The poultry red mite (Dermanyssus gallinae): a potential vector of pathogenic agents. Experimental \& 
Applied Acarology, v.48, n.1-2, p.93104, 2009.

MURILLO, A. C.; MULLENS, A. B. Sulfur Dust Bag: A Novel Technique for Ectoparasite Control in Poultry Systems. Journal of Economic Entomology, v.109, n.5, p.2229-2233, 2016.

NORDENFORS, H.; HOGLUND, J.; TAUSON, R. et al. Effect of permethrin impregnated plastic strips on Dermanyssus gallinae in loose-housing systems for laying hens. Veterinary Parasitology, v.102, n.1-2, p.121-131, 2001.

OLIVEIRA, D. G. P.; BONINI, A. K.; ALVES, L. F. A. Field Assessments to Control the Lesser Mealworm (Coleoptera: Tenebrionidae) Using Diatomaceous Earth in Poultry Houses. Journal of Economic Entomology, v.110, n.6, p.2716-2723, 2017.

PAPPAS, J. L.; STOERMER, E. F. Quantitative method for determining a representative algal sample count. Journal Phycology, v.32, n.4, p.393696, 1996.

PEREIRA, M. C. Ectoparasitose. In: REVOLLEDO, L.; FERREIRA, A. J. P. (eds). Patologia Aviária. $1^{\text {a }}$ ed. Barueri: Manole, 2009, Cap.34, p.322-327.

PRITCHARD, J.; KUSTER, T.; SPARAGANO, O. et al. Understanding the biology and control of the poultry red mite Dermanyssus gallinae: a review. Avian Pathology, v.44, n.3, p.143-153, 2015.

PÜNTENER, W. Manual for field trials in plant protection. Basel: Ciba-Geigy Limited, 1981, 271p.

ROMÃO, G. O. Ocorrência de resíduos de dimetoato e aldicarb em ovos produzidos na região norte do estado do Paraná. 2007. Londrina (Pr), 44f. Dissertation (Mestrado em Ciência Animal) - Universidade Estadual de Londrina.
ROSEN, S.; YERUHAM, I.; BRAVERMAN, Y. Dermatitis in humans associated with the mites Pyemotes tritici, Dermanyssus gallinae, Ornithonyssus bacoti and Androlaelaps casalis in Israel. Medical and Veterinary Entomology, v.16, n.4, p.442-444, 2002.

ROUND, F. E.; CRAWFORD, R. M.; MANN, D. G. The diatoms: biology and morphology of the genera. New York: Cambridge University Pres, 2005, p.760.

SANTESSON, S. Evaluation of Ectopar for the control of the poultry red mite Dermanyssus gallinae. 2013. Uppsala, 30f. Degree project (Faculty of Veterinary Medicine and Animal Science) - Swedish University of Agricultural Sciences.

SARWAR, M. Inorganic insecticides used in landscape settings and insect pests. Chemistry Research Journal, v.1, n.1, p.50-57, 2016.

SCHULZ, J.; BERK, J.; SUHL, J. et al. Characterization, mode of action, and efficacy of twelve silica-based acaricides against poultry red mite (Dermanyssus gallinae) in vitro. Parasitology Research, v.113, n.9, p.3167-3175, 2014.

SPARAGANO, O. A. E.; GEORGE, D. R.; HARRINGTON, D. W. J. et al. Significance and Control of the Poultry Red Mite, Dermanyssus gallinae. Annual Review Entomology, v.59, n.1, p.447-466, 2014.

STATSOFT. Statistica: data analysis software system. Version 7.0. TulsaUSA. 2004.

WATSON, D. W.; DENNING, S. S.; ZUREK, L. et al. Effects of lime hydrate on the growth and development of darkling beetle, Alphitobius diaperinus. International Journal of Poultry Science. v.2, n.2, p.91-93, 2003. 
WU, J.; YANG, Y. S.; LIN, J. Advanced tertiary treatment of municipal wastewater using raw and modified diatomite. Journal of Hazardous Materials, v.127, n.1-3, p.196-203, 2005. 